\title{
The Necessity and Importance of Mortuaries for Towns and Villages, with some suggestions for their Establishment and Management.
}

THE subject of mortuaries is one that has received by far too little attention, not only at the hands of those who are responsible for the practical carrying out of the public health laws of the kingdom, but even of ardent sanitary reformers. Yet it holds, or ought to hold, a prominent place in preventive medicine; and it differs from other sanitary appliances in having an important moral and social office as well as a hygienic one.

To an assembly like this it might perbaps be considered superfluous that I should attempt to show cause why mortuaries are necessiry or desirable. Most of us, and especially those whose work has brought them into relations with the poor and the degraded, know what additional terrors death brings with it when it occurs in wretched tenemented property, or in overcrowded cottage bomes, where the same room has to act as dead-house, living room, workroom, and not infrequently bedroom. In the poorer parts of our great towns, and, to a lesser degree, perhaps, in country villages, scenes of the most harrowing and saddening description are constantly being enacted through the unavoidable presence of the dead in the midst of the living. Perhaps no more striking demonstration of the need for mortuaries has been made than in the writings of one who is well known to and honoured by all of us-our veteran vice-president, Edwin Chadwick. It is to him that we owe, more than to anyone else, that sanitary awakening which has now become so general and widespread, and of which one of the strongest evidences is the existence and success of this Institute. Mr. Chadwick, to whom had been committed early in the present reign the task of collecting information about the sanitary state of the country, and subsequently as to the practice of interment in towns, wrote as follows in the year $1843^{1}$; and his words are equally applicable at the present moment :

- In a large proportion of cases in the metropolis, and in some of the manufacturing districts, one room serves for one family of the labouring classes : it is their bedroom, their kitchen, their wash-house, their sitting-room, and their dining-room; and when they do not follow any outdoor occupation, it is frequently their work-room and their shop. In this one room they are born, and live, and sleep, and die, amidst the other inmates. . . .

'It is not a few minutes' look after' the last duties are performed

${ }^{1}$ A Supplementary Report on the Results of a Speciul Inquiry into the Practice of Interment in Towns. By' Edwin Chadwick. London. WV. Clowes \& Suns, 1843. 
and the body is composed in death and left in repose, that is given to this class of survivors, but the spectacle is protracted hour after hour through the day and night, and day after day, and night after night, thus aggravating the mental pains under varied circumstances and increasing the dangers of permanent bodily injury. The sufferings of the survivors, especially of the widow of the labouring classes, are often protracted to a fatal extent. To the very young children, the greatest dinger is of infection in cases of deaths from contagious and infectious disense. To the elder children and members of the family and inmates, the moral evil created by the retention of the body in their presence beyond the short term during which sorrow and depression of spirits may be said to be natural to them is, that familiarity soon succeeds and respect disappears. These consequences are revealed by the frequency of the statements of witnesses, thit the deaths of children immediately following, of the samo disease of which the parent had died, had been accounted for by 'the doctor,' or the neighbours, in the probability that the child had canght the discase by touching the corpse or the coffin whilst playing about the room in the absence of its mother. The mental effects on the elder children or members of the fimily, of the retention of the body in the living room day after day, and during meal times, until familiarity is induced-retained as the body commonly is cluring all this time in the sordes of disense, the progress of change and decomposition disfiguring the remains and adding disgust to familiarity-are attested to be of the most demoralising character. Such deaths occur sooner or later in various forms in every poor fimily; and in neighbourhoods where there are no sanitary regulations, where they are ravaged by epidemics, such scenes are doubly familiar to the whole population.'

The same graphic pen thus writes in the rejort of the Board of Health on a general scheme for extramural sepulture, published in 1850 :-

'The connection between the extinction of the feeling of respect for the dead and the growth of that callonsness which renders the brutalised mind insensible to the sacrerlness of life, and which thus prepares it for the perpetration of crimes of violence of the greatest enormity, has been often traced by those who hive had the best opportunity of witnessing the process; and they concur in stating that it is in these filthy, unwholesome, and crowded rooms, where none of the observances of decency are regarded, and where the living, without emotion or concern, eat and drink and sleep in the presence of the dead, not only that the degraded and profligate who constitute the ordinary pests of society are trained, but also that it is out of those same abocles that our great criminals generally come, brutal and reckless men, who every now and then perpetrate in cold blood, with a savage callousness, deeds which fill the whole country with disgust and horror.'

I do not quote any of the instances which Mr. Chadwick cites, on the authority of clergymen and undertakers of that period, of the distressing scenes that they were constantly called upon to witness where a death occurred under conditions that absolutely precluded any separa- 
tion or screening of the dead from the living. It might be argued that a generation, and the passing of numerous sanitary Acts of Parliament, have worked a revolution in this respect since Mr. Chadwick's glowing words were witten. I can confidently affirm, however, from a pretty large experience of the slums of London and of other towns, that scenes not a whit less distressing or heartrending than those described forty years ago are still matters of common experience among our poor and degraded neighbours.

I feel bound, in justification of the position which I have assumed, and in order that I may not seem to bo speaking without book, to cull a ver'y few from the large number of instances that have come under my notice in one way or another, pointing to the necessity and importance of mortuaries. They are instances which every health officer, and every one'who moves among the poor, could multiply a hundred-fold.

Cases of the kind to which I am referring are constantly occurring in the experience of London coroners, whose evidence on this subject would be of the most instructive and startling kind. The dead body of a woman on whom an inquest was held by Dr. Hardwick in 1876 was kept in a miserable underground kitchen where the family lived; and where, after the work, the family slept and took their food by the side of the corpse until the buxial took place. ${ }^{1}$

In a speech made before Mrr. Sclater-Booth, in January 1876, Dr. Joseph Rogers cited the following case: An old man died in a house in St. James's let ont to lodgers, As it was thought his friends would bury the body, it was allowed to remain several days : indeed, until decomposition had so far advanced as to fill the house with effluvia. The sanitary inspector was then applied to, who, in his turn, applied to the master of the Westminster Workhouse for permission to take the body to the workhouse dead-house. The body was so putrescent that the worklouse attendants had to fill the shell with charcoal ere they dared to take it through the streets. ${ }^{2}$

At a meeting of the West Derby Local Board in March 1876, the sanitary inspector reported that in the course of his duties he had visited a house on the $23 \mathrm{rd}$, and had found the body of a woman who had diecl on the 19th, lying in one of the rooms which was used as the sleeping-room of the family. The husband stated that as he was too poor to inter the body, he had applied to the relieving officer to have it buried, but the request had been declined by the Board of Guardians. He then went to the clerk to the Local Board, who, after some delay, got an orter from a magistrate, and the body was buried six clays after death. The husband, who was represented to be given to drink, and indiffcrent as to whether the body was buried or not, had slept, it was said, in the same bed in which the corpse lay. ${ }^{3}$

The corpse of an unhappy youth at Milton-next-Sittingbourne, who died in a barge from typhoid fever, contracted through drinking

1 Sanitary Record, 1876, vol. iv. p. 162.

2 Ibid. 1876, vol. iv. p. 43.

3 Ibid. 1876, vol. iv. p. 252.

H 2 
polluted water, was brought to his parents' house through the streets in an open van. On the arrival of the body, the coffin was unscrewed, and remained so for two days before the burial. An outbreak of typhoid fever, confined to the street in which the body lay, subsequently broke out, and may possibly have been due to infection from the corpse. ${ }^{1}$

M. Kochlin-Schwirtz recently narrated to a commission of the French Society of Public Medicine-a society which has lately devoted much attention to the subject of mortuaries - a very painful case. In a small room rented by a workman, the father, attacked by small-pox, lay dying on the only bed, and round him, his wife and his five children, without fire or food, were waiting in clespair till their turn came to be struck down by the disense. The mother, indeed, was in the anguish of child-birth whilst her hushand was in extremis. ${ }^{2}$

Quite recently, in fact during the present month, two other glaring cases have been reported in the metropolis, where the great want of public mortuaries is being daily illustrated by the occurrence of cases shocking public decency and detrimental to public health. In one case, in which Mr. Humphreys held an inquest into the cause of the death of a labourer at Mile End, the jury having viewed the body, made, on their return, a complaint to the coroner of the unseemly sight which they had just been obliged to witness. The body lay in a very small and squalid room, in which the relatives, three in number, were sleeping, and had to be aroused before the jury could perform their duty. The foreman justly observed that such a state of things ought not to be permitted to exist in an enlightened country. The coroner's officer explained that there was no public mortuary in the parish of Mile End New Town, or he should have taken the earliest steps to have had the body removed. The coroner could only recommend the foreman to make a representation of the facts in the proper quarter. Dr. Hirdwicke, the coroner for Central Middlesex, on the occasion of holding two inquests at the Hampstead Workhouse Infirmary, also called attention to the inconvenience which has long been felt by medical men and others having any connection with inquests at Hampstead, in regard to the want of proper mortuary accommodation. The building at present used for that purpose is the workhouse dead-house, situated at one of the extreme ends of that extensive parish, and is not properly fitted with appliances for postmortem examinations. Dr. Hardwicke said he had been requested by medical men and otbers to draw the attention of the jury to this matter. It was thought that the time had arrived when they should make some representation to the parish authorities on this subject. The present mortuary was a place for paupers, and it was not proper: that the bodies of those who were not paupers should be taken to it. The medical men engaged, too, had not the proper apparatus with which to do their work. Another grievance was that persons dying in a distant part of that large parish had to be brought to that place. If it were the opinion of the jury that a more central place should bo provided, quite apart from the workhouse, he would offer a memo-

I British Medical Journal, 1879, vol. ii. p. 603.

2 Revue d'Hygiène, tome ii. p. 41. 
rial for them to sign. The jury agreed to this suggestion; and a memorial was drawn up and signed by the jurors and other's, and is to be followed by another from the medical men of the parish. ${ }^{1}$

One more example, and I have done. There are few amongst those present who do not know the labours amongst the poor of the Rev. Septimus Hansard, the rector of Bethnal Green. On the occasion of the recent opening of a mortuary for his crowded parish in June last, Mr. Hansard said :-

' The use of the building was two-fold-(1) As a mortuary or morgue for the reception of dead bodies, suicides, persons found drowned, nameless corpses, \&rc. (2) As a mortuary chapel. It was impossible to have been as he had been-for the last 33 yen's a clergyman among the poor of London-without seeing the necessity for some such building as this, whither the inhabitants of the crowded dwellings of the metropolis might remove their dead, especially in times of epidemics such as cholera, scarlet or typhus ferer. He gave three instances of such necessity out of many in his experience. In the time of the cholera, there was one night when nine lay dead of cholern in the houses of the church-close or square near the parish church. The people all sat about in the streets, too frightened to go to bed; and in one place they were burning pots of tar from the windows of the room where a corpse lay. Again, it had in the course of his ministry been his duty to attend two medical men on their death-bed who, in the fearless discharge of their profession, had fallen victims to confluent smallpox. On both occasions the relatives had immediately after cleath removed the bodies to outhouses. On another occision he saw, in a room not larger than an ordinary closet, three victims of typhoid lying dead, with five people eating, drinking, sleeping, and living in the sume room. Things like this in a professedly religious and Christian country were disgriceful. Here, surely, were proofs of the need of such a mortuary chapel as had just been opened. But not only in case of epidemics would this building be used, but at ordinary times. There were two rooms in the chapel, each capable of containing thirty coffins. One might be set apart for those which required an inquest, or for infections bodies, the other for those brought thither by sorrowing friends, who could cover the coffin with a pall, and come and take their last look at their beloved ones, surrounded by the emblems of Christian hope. That was why he had desired the building to be called a chapel; not that masses for the dead should be said there, but to throw the sanctity of religion over the building.'

The experience of many of you will furnish other equally striking cases, and I need not, therefore, detain you further with citing more. All sanitarians agree in thinking that in large or crowded towns a properly constructed mortuary is of the first necessity : and there are reasons for thinking that in rural districts also, some provision of the kind would be extremely valuable and save much present scandal. The dwellings of agricultural labourers and their often indecent overcrowding need no description at my hands : and what is to be done in such when a death occurs? Evidently the dead must be left in very unwholesome and distressing proximity to the living in the

1 British Afedical Journal, 1880, vol. ii. p. 517. 
absence of a mortuary or clead-house, which thus becomes a necessity throughout the countiy.

Having in this way attempted to place graphically before your minds the horrors and dangers of the dend remaining amongst the lixing in poor and wretched homes, I would now draw your attention to the remedy, viz. the provision of reception or deal-houses, in which corpses may remain pending interment.

The able and comprehensive report by Mrr. Chadwick, to which I have already alluded, may fairly be considered as the starting point, amongst other things, of mortuaries. The report was published in 1843, and evoked much attention and discussion. With the exhaustive report which preceded it, on the sanitary state of the labouring population of Great Britain, it unquestionably paved the way for the passing of the Public Health Act of 1848. In that Act (11 and 12 Vict., cap. 63) there was a section (No. 81) which provided that for the regulation of interments in districts to which that Act applied, Local Boards might provicle reception houses for the dead, and make bye-laws with respect to the management of the same, and on application, make arrangements for the interment of any corpse contained therein. This clause was practically superseded by section 27 of the Sanitary Act, 1866, but was not formally repealed until the Consolidating Act of 1875 .

The law remained, as regards sanitary authorities, in this state for nearly twenty years, but meanwhile the subject had received a certnin amount of attention both at home and abroad. In 1852 there was a general Sanitary Congress at Brussels, and part of the third question for discussion was: 'Of what utility are mortuaries, and for the cases in which their usefulness is recognised, how should they be organised?' I rejoice to find that amongst those who made a firm stand on that occasion for this question being one proper for discussion by the Congress (in opposition to those who would have ignored it, on the ground of its touching questions of religious feelings and family affection) our honoured President, then Lord Ebrington, made himself conspicuous. After discussion, the Congress declared the usefulness of mortuaries in each parish ; and, on the motion of Lord Ebrington, resolved that: 'Convinced of the great evils of the keeping of corpses in inbabited rooms, the Congress declares the usefulness and earnestly recommends the establishment of mortuaries.'

Whilst as regards the provision of mortuaries by sanitary authorities no further legislation was attempted until 1866, an important addition to the law was meanwhile made by giving power to the Buxial Boards established under the Burial Acts to provide such a building. Thus, section 42 of the Metropolitan Burials Act of 1852 (15 and 16 Vict. c. 85) gave power to any Burial Board, or to the churchwardens and overseers of any metropolitan parish for which a Burial Board had not been appointed under the Act, to 'hire, take on lease, or otherwise to provide fit and proper places in which bodies may be received and taken care of previously to interment, and to make arrangements for the reception and care of the bodies to be deposited therein.' . 
This power was extended to places beyond the Metropolis by section 7 of the Burials Act of 1853 (16 and 17 Vict. c. 134); to Scotland by section 20 of the Scotch Burials Act of 1855 (18 and 19 Vict. c. 68); and to Ireland by section 23 of the Irish Burials Act of 1856 (19 and 20 Vict. c. 98), now replaced by section 180 of the Public Health Act of 1878 (41 and 42 Vict. c. 52).

The Sanitary Act of 1866 (29 and 30 Vict., c. 90) improved the state of the English law as to mortuaries. By section 27 of this Act 'nuisance authorities' (equivalent to our existing local authorities) were empowered to provide a proper place for the reception of dead bodies, and thereupon a justice, with a medical certificate, might order bodies to be removed to it, and cause removal if the relations failed to obey, charging them with the cost. The authorities were also empowered to provide places for post-mortem examinations (section 28).

The Royal Sanitary Commission, commenting upou section 27, observed that 'although there is this power by law, it appears to be very little exercised, and the evil of keeping the dead in the same room with the living exists very extensively amongst the poor, and this evil is aggravated by the general practice of wakes among the lower classes of the Irish Roman Catholics, who are very numerous in some large towns, such as Liverpool. ${ }^{1}$

The Commissioners suggested that power should be given to the Central Authority to compel a Local Authority to provide a mortuary; and that, even when there was no mortuary, the justice should be enabled, in the cases specified in section 27 of the Sanitary Act, to give an order for the removal of the body from the house. To facilitate the acquisition of parts of closed burial grounds or of land in cemeteries for mortuaries, the Commissioners suggested that the Local Authority should be empowered, in the case of any closed burial ground, to purchase by contract any part of such burial ground from those in whom the site and control were vested, for the purpose of erecting thereon a mortuary, and (if needful) a residence for the keeper. The Commissioners formulated, however, certain provisoes to this transfer, and as these provisoes contain much suggestive matter in a small compass, I give them in full :-

' 1 . This shall not authorise the purchase of any piece of land if it necessitates the disturbance of bodies already buried.

' 2 . Nor if the piece to be purchased cannot be approached without passing through any other part of the closed burial ground.

' 3 . No religious service shall be held or celebrated in any mortuary erected in any closed burial ground.

4. Such mortuary and residence house (if any) shall be separated by a wall or fence from the rest of the burial ground.'

The Consolidated Public Health Act of 1875, whilst re-enacting the sections of the Act of 1866 as to mortuaries, made their provision by the Local Authority compulsory in cases where the Local Government Board required. The Act of 1875 does not, however, extend to the Metropolis, which; in this respect, is worse off than the country, for the Local Government Board have not the power, even if

2 Second Report of the Royal Sanitary Commission, vol. i. p. 50. 
they felt inclined to exercise it, to compel the erection of a mortuary in London. In Scotland legal power is given by section 43 of the Public Health Act of 1867 (30 and 31 Vict. cap. 101) to provide a place for the reception of dead bodies, and to remove bodies to it in certain cases. Nothing is said, however, with regard to post-mortem rooms. In Ireland provisions similar to those in the English Act are contained in sections 157, 158, and 159 of the Public Health (Ireland) Act, 1878 (41 and 42 Vict. c. 52), and there is this important addition: 'The body of any person who has died of any dangerous infectious disease in any hospital or place for the treatment of the sick shall not be removed from such hospital, until removed direct to a mortuary or cemetery, and any person violating, or any officer of an hospital or other person who knowingly permits the violation of this provision, shall be liable to a penalty not exceeding five pounds.'

Seeing the unsatisfactory state of the law, Dr. Joseph Rogers, whose services in connection with sanitary work are well known, and who, some 24 years before, had the principal share in the establishment of the mortuary at St. Anne's, Soho, which was for several years the only one in the Metropolis, moved, in the year 1875, at the Strand Board of Works, that "With the view of the more effectually and economically securing the establishment of mortuaries in the different parishes of the Metropolis, this Board do memorialise the Metropolitan Board of Works, urging that Board to apply for powers in the next Session of Parliament, authorising that body to undertake their erection in such parts of the Metropolis as may be considered necessary.' The Metropolitan Board declined however to take up the subject, on the grounds that the mortuary question is beset with difficulties in London, and is one which should be dealt with by the Local Boards and not the Metropolitan Board. ${ }^{1}$ The Strand Board of Works deemed it necessary, however, to interview the then President of the Local Government Board, for the purpose of securing the aid of his Department in establishing mortuaries in different parts of the Metropolis. A deputation from that body waited upon Mr. Sclater-Booth in January 1876, when Dr. Rogers made a lengthy and telling speech in favour of the extension of mortuaries, winding up by formulating the points that should be attended to with reference to the question." These were: ' 1 . That it should be made compulsory on every Local Board to establish a suitable mortuary on a common plan, to be approved of by the Local Government Board or the Metropolitan Board of Works. 2. That these mortuaries should be in the proportion of not less than one to every 50,000 inhabitants. 3. That powers should be provided for the compulsory purchase of property under the provisions of the Lands Clauses Act, and for enabling parishes or portions of parishes favourably situated for such purposes to combine to form mortuary districts; such mortuaries to be maintained at their joint expense, and for their common use. 4. That the Medical Officer of Health, or the Poor-law Medical Officers, or the

1 Sanitary Record, vol. ii., 1875, pp. 165 and 325.

2 Ibid. vol. iv. 1876, p. 44. 
Relieving Officer, should be empowered and directed to order the removal of a corpse to the district mortuary in all cases where it was found that the family, at the time of such death, occupied only one room, and in such other instances where it appeared desirable to these officials to direct the same.'

Not much of promise was extracted from Mr. Sclater-Booth : but he undertook to confer on the subject with $\mathrm{Mr}$. Cross, who as Home Secretary had more control over the Vestries than the Local Government Board had. In the ill-fated Public Health (Metropolis) Bill of 1877 , which Mr. Sclater-Booth introduced with the view of making the public health law uniform for the metropolis and country, clauses were inserted re-enacting the clauses in the Sanitary Act, 1866, bearing on the question, but making the provision of a mortuary compulsory, if the Local Government Board so directed. The fate of this Bill is, however, well known; and we are now in the Metropolis almost as badly off as ever, certainly as badly off for any reasonable system of disposing of the dead pending interment. I think, therefore, that this is a subject which is eminently worthy of the attention of the Sanitary Institute, and I would suggest for consideration, whether it might not be expedient and useful for the Institute to take up the question where it was left in 1876, and endeavour to induce the new Government to make a move with regard to this important branch of public health machinery.

I now come to the second part of my paper, and proceed to offer some suggestions for the establishment and management of mortuaries.

I must premise that these suggestions are not intended to exhaust the subject. They are suggestive merely, and are offered in the hope that they may help to a better understanding of a question on which far too little is known. Not the least of my difficulties in approaching this subject has been the extreme paucity of the information given about it by standard authorities. ${ }^{1}$ The word mortuary hardly occurs in the index to any book on Hygiene with which I am familiar. I bave therefore had to rely very much upon the facts which $I$ have been able to pick up in the course of my reading, and upon my practical experience of the requirements of such erections. ${ }^{2}$

It may be, and has been, urged against the erection of mortuaries, that even if they were established, poor people would with difficulty be got to allow their dead to be taken there. The law recognizes this difficulty, and section 142 of the Public Health Act provides that 'when the body of one who has died of any infectious disease is

1 Sanitary Record, January 15, 1876, p. 44.

- For much valuable information showing the need for mortuaries, reference may be made to Mr. Chadwick's Report on the Practice of Interment in Towns (Clowes, 1843), and to the Report of the General Board of Health On a General Scheme for Extrumural Sepulture (Clowes, 1850). Dictionary articles on the subject will be found in Tardieu's Dictionnaire d' Hygiene, article 'Morgue' (Baillière, Paris, 1862), Wynter Blyth's Dictionary of Hygiene, article 'Mortuary' (Griftin, London, 1876); and Pappenheim's Handbuch der Sanitäts-Polizei, article 'Leichen-polizei ' (Hirschwald, Berlin, 1870). In the second edition of the writer's book on Cottage Hospitals (Churchill, 1880), an attempt has been made to deal with the question of mortuaries, more particularly from the point of view of their relation with hospitals. 
detained in a room in which persons live or sleep, or any clead body which is in such a state as to enclanger the health of the inmates of the same house or room, is retained in such house or room, any justice may, on a certificate signed by a legally qunlified medical practitioner, order the body to be removed at the cost of the Local Authority, to any mortuary provided by such authority, and direct the same to be buried within a time to be limited in such order.' This section, it will be observed, is of very wide application ; for it cannot be doubted that many dend bodies, not necessarily those of persons dying of an infectious disease, are in such a state as to endanger the health of the living inmates of the house or room in which the bodies are retained. Yet, unless a mortuary is provided, there is no legal power to deal with the body, and it may remain a source of the gravest injury to the public health of the neighbourhood. The establishment of a mortuary is then an imperative duty for Local Authorities throughout the kingdom.

Mortuaries have been provided in this country in a great variety of ways. There are first of all the separate erections, with postmortem room and coroner's court, such as the mortuaries in the City of London, at Islington, Clerkenwell, and in some of our large towns. There are the mortuaries provided by sanitary authorities in connection with infectious hospitals that they have established. There are the mortuaries provided at cemeteries or on licensed burial grounds. And there are the mortuaries, if such they can always be called, provided at' general hospitals for the bodies of persons dying in the institution, but rarely thrown open to the outside public. Of the latter I do not intend to speak. These are not public mortuaries in any real sense of the word. They are simply furnished for the convenience and use of the hospital authorities and for post-mortem purposes, and are intended in addition for the purpose of keeping the corpses out of the wards until the time comes for burial. Indeed, it may safely be said that no mortuaries in any comprehensive sense of the word exist at hospitals.

Of mortuaries proper, all sorts and sizes exist, from the elaborate erection provided at a cost of $12,000 l$, by the City Commissioners of Sewers, in Golden Lane, comprising a mortuary chapel, with twelve slate tables, keeper's house and offices, coroner's court, laboratory, weighing room, consulting room, dead-house fitted for post-mortem examinations, disinfecting apparatus, ambulance shed, and shed for disinfecting apparatus, down to the old parish dead-house or pest-house, which has in some places been utilised for the purpose, and is almost, if not quite, destitute of all furniture.

One of these pest-houses is to be found at Greenwicb, where it stands in the churchyard, to the disgrace of the local health authority.

I do not propose, in fact it would be impossible for me, to attempt to give any sort of description of the mortuaries which at present exist. They are too various in establishment, size, arrangement, regulation, and management, to admit of any sort of classification; and I have therefore contented myself with giving in an Appendix the names, and all procurable particulars of those mortuaries of which 
I have been able to learn the existence. I am conscious how extremely clefective this list is, and I shall be greatly obliged for any further names and particulars with which I may be favoured.

I proceed then at once to sketch out certain requirements of a mortuary, as regards its establishment, situation, and regulation.

And first, as to its establishmont. I have already mentioned in a former section that, under the Public Health Act of 1875, any Local Authority may, and, if required by the Local Government Board suall, provide a mortuary, and may make bye-laws with respect to the management and charges for its use. They may provide for the decent and economical interment of any clead body received into a mortuary (Section 141). To this mortuary, a justice may, in certain cases, order the removal of a dead body (Section 142). The Local Authority may also provide a place for post-mortem examinations ('otherwise than at a workhouse or a mortnary') (Section 143). Thus it is to local sanitary authorities that we must mainly look for the establishment of these temporary resting-places for the dead. But it has struck me that when the Local Authority is unwilling to perform this necessary duty, or has difficulty, -wbich I know to be sometimes a real difficulty,-in procuring a suitable site, that then another method might, in places where there is a hospital, be devised for securing the establishment of a mortuary. Most hospitals make some sort of provision for deaths occurring within their walls; and I think that if sanitary authorities felt disposed to help, hospital managers would often be found willing to erect a somewhat more pretentious mortuary than they would otherwise have done, and to throw it open, under certain regulations, to the general public. The rapid extension of cottage hospitals leads one to hope that this method of securing mortuaries would satisfy the demands of a large and increasing number of places. It is a common practice for Local Authorities to subscribe to hospitals, - especially to infectious hospitals, provided by private enterprise; and I am not aware of any legal objection to the same power of subscription being exercised in the case of mortuaries. Indeed, the utility of a mortuary is usually more obvious to Local Authorities than that of a hospital, so that probably this plan has only to be suggested to secure adhesion to it.

Another method in which mortuaries-especially on the continent -are provided, is to erect them in cemeteries. There is much to recommend this plan, both on the score of economy and of regard for the public health, so long as the cemetery is within reasonable distance of the district for which the mortuary is to serve. Such mortuaries are of course provided by Burial Boards, who need not be, and as a rule are not, the 'sanitary authority of the place. In this connection, it may be wortl while to observe that, whilst section 142 of the Public Health Act grants the power of compulsory removal of dead hodies to a mortuary provided by a sanitary authority, it does not do the same in the case of a mortuary provided by a Burial Board. This seems a very absurd and unnecessary restriction, and may be commended to the attention of our legislators. In addition to the advantage of freer space and cheaper administration,-for the cemeteryleeper could be instructed to supervise the mortuary as part of his 
duties,-mortuaries at cemeteries enable the corpse to be taken direct to the grave, without the necessity of a hearse and its attendant expenses. At the mortuary established by the Hampstead Burial Board at their cemetery at Fortune Green, there is a wholesome rule requiring that, in the case of persons dying of infectious disease whose corpses are received into the mortuary, the friends must meet the corpse at the cemetery, and not at the mortuary, from which the body is carried clirect to the grave. For ordinary cases of death, it would be well to have a separate waiting-room provided for the mourners to assemble in on the day of burial, as is done at the mortuary in Dean Street, Soho. Seeing, then, the obvious advantages of mortuaries at cemeteries, it may be worth consideration whether, in the establishment of all new cemeteries, provision should not be made in the plans for a building, of the nature of a mortuary, to receive dead bodies pending interment. On this point, the evidence of the late Mr. Robert Baker, one of Her Majesty's Chief Inspectors of Factories, is peculiarly valuable. When examined before the Royal Sanitary Commission, on January 17, 1870,' Mr. Baker said that he 'wished strongly to express that he thought at ever'y cemetery there should be a mortuary for from one to fifty bodies, with locks and keys, the numbers of the cells and keys to correspond: and he thought it would be desirable, in non-contagious deaths, that the bodies of the poor should be conveyed, soon after death, to these mortuaries, and, if the people were needy, at the public expense; and the key should be given up to the relatives to the time of interment, which should be fixed, in order to avoid offence in the summer time' (Q. 9407). Asked whether he would make the removal optional in non-contagious diseases, and compulsory in the case of contagious diseases, he answered in the affirmative; and he thought that ' in case of contagions diseases, it should be compulsory to have the body placed within a shell, within a coffin (if it be desirable that it should be kept for the arrival of friends), between which and the shell there should be an interstice of pitch; the lid of the shell being also pitched on, but with a glass over the face' (Q. 940s). The expense of such removal Mr. Baker would, in the case of poverty, throw upon the parish. ${ }^{2}$

We have next to consider the question of situation. Whenever possible, the mortuary should of course be separated by a belt of air from all dwelling-houses; but no injury has been found to follow the use of those in very crowded neighbourhoods, even when they abut on the street. The mortuary in Drury Lane, the walls of which are brought up flush with the pavement, is an instance of this. The

1 Second Report of the Royal Sanitary Commission. vol. iii. Part I. p. 53.

2 Mr. Thomns Baker, in his standard work on The Laws Relating to Burials (Mnxwell \& Son, 1873), remarks, on page 304 of the fourth edition:- In some of the more recently erected cemetery-chapels an arrangoment his been made which might serve some of the purposes of places for the temporary reception of the dead before burial as well as their chief object, that of protecting the mourners attending the funeral services from annoying or dangerous emanations from the dead. In these chajels a portion has becn divided off from the main building by a glass screen, which completely separates the part in which the cothins are placed from that occupied by the mourners, and it is ensy to make this separated portion large enough to hold several coftins, where they might remain without danger until preparation is made for the funeral.' 
Drury Lane mortuary, like a grent many others in the Metropolis, has been built on an old disused burial ground; and certainly these spaces, occurring as they do in crowded localities, afford a very convenient site for morturies, a site, too, which the ordinary prejudices of people against the establishment of receptacles for the dead in their midst can hardly reach.

Wherever possible a mortuary should be screened from the road by trees or shrubs, and should be approached by a winding path also planted with shrubs.

The internal arrangements and fittings are most important. There should be ample means of ventilation provided for every part of the building; and the mortuary, though not made too bright by window space, should not be gloomy or depressing in appearance.

Though, of course, a mortuary proper would consist merely of a dead-house, it is very desirable, and indeed essential, that connected with it should be a room for post-mortem examinations, and another for the holding of coroners' inquests. For it must be remembered that a certain, and in some cases not inconsiderable, portion of the bodies brought into a mortuary will be for identification and legal inquiry - as of persons found drowned, or dead in the streets, murders, suspected suicides, unknown strangers at hotels, \&c., \&c., and suitable provision must therefore be made not only for a skilled medical examination of the body to discover the cause of death, but also for the coroner and jury to hold inquests on the bodies.

The most objectionable and undignified custom of holding inquests at inns and taverns, - not unfrequently amidst the noise and bustle of business in a low neighbourhood,-hardly needs condemnation at my hands. It has been satirised by sever'al of our great writers, foremost amongst them being Dickens, whose vivid word-picture of the coroner's inquest in 'Bleak House' is doubtless familiar to you all. If all mortuaries had a room fitted up as a coroner's court, the present indecency of inquests might to a large extent be done away with.

The size of the mortuary room proper must, of course, be large, and will depend upon the population of the district for which it is to serve. Space for some twelve bodies has been held by Dr. Hardwicke, the able and energetic coroner for Central Middlesex, to be quite sufficient for a large town. The bodies may be placed in shells or coffins resting either upon tables covered with zinc or other impermeable material, or upon trestles, or upon moveable iron brackets fixed round the walls. At some of the London hospitals, catacombs the size of the coffin, and made of slate or brickwork, are used; and for certain purposes these may be found useful.' Since some of the bodies are certain to be brought in an advanced stage of decomposition, a stock of charcoal and disinfectants should be kept. Any good disinfectant may be employed, but as the chlorides act most powerfully in preventing decomposition, it would, perhaps, be preferable

1 In certain cities of the Continent there are mortuary cluambers in the form of separate cells completely isolated, in which it is contemplated that families can mourn and watch their dead until the time comes for interment. These, as being wholly religious structures, I do not propose to deal with. 
to use them. If carbolic acid be employed, a strong solution must be used. If the dend are in an advanced state of decomposition before they are received, they shonld be surrounded with sawdust and carbolic acid powder before being screwed down, to prevent annoyance and injury to health. Cloths for covering the dead, which should be frequently saturated with disinfectants, should be provided.

It is important that the mortuary should have in readiness some shells or coffins for the holding of corpses whilst a proper coflin is being prepared. It has been suggested that the person desiring to make use of the mortuary should provide these: but experience teaches-as indeed was to be expected-that it is far preferable for the managers of mortuaries themselves to have on hand a few such shells, which can be sent from the mortuary to the place from which the body has to be removed. The Islington Vestry, having experienced difficulties in the use of their admirable mortuary with regard to this question of shells, ordered some of different sizes, made of wood and lined with tinned copper, to be kept at the mortuary for use when required. These are cleansed by the mortuary keeper after each occasion of use. A good rule at this mortuary is that no wooden shells may be removed therefrom except when used to bury in. If a body be transferred from it to a coffin for burial, the shell is sprinkled with disinfectants, split up and burned. At Clerkenwell, the City, and Drury Lane mortuaries, there are also shells belonging to the authorities in rendiness for similar emergencies. At every mortuary there ought to be at least one or two air-tight coffins with glass lids for convenience of viewing the bodies on which inquests are held-an oftentimes very distressing and disgusting ceremony for the jurors. Or a well-made movable case with glass on the top might be provided for placing over bodies on which inquests are to be held. The glass should be fixed in a frame hung on hinges, so as to admit of the free use of disinfectants after the case has been placed over the body.

The post-mortem room may adjoin, but should be quite distinct from, the mortuary. This separation is needful in order to comply with the terms of section 143 of the Public Health Act, which, whilst giving powers for the erection of post-mortem rooms, distinctly requires that they must be provided "other than at a workhouse or a mortuary.' Mr. Lumley, in his comments upon this section, observes that "This exception deserves special attention. It is desired that places should be provided for the removal of dead bodics from the rooms of poor people when they die, and it wonld create a repugnance on the part of the relatives to such removal in many cases, if a suspicion arose that such bodies might be sulject to anatomical examination. ${ }^{1}$ This, no doubt, is the feeling which has prompted the legislature to make so positive a prohibition. It is only necessary; however, to talke care that the post-mortem room is distinct from the mortuary (i.e. that it is walled off from it, has a separate entrance, and is cut off from it in other ways), to comply with the Act of Parliament.

1 The Public Health Act, 1875, Annotated. By W. G. Lumley, LL.M., Q.C. (Shaw \& Sons, 1876), p. 115 . 
As to the fittings of the post-mortem room, I cannot do better than quote from a paper on the subject of mortuaries which was read before this Institute at its Stafford meeting in 1S78, by Dr. Hardwicke, whose very large experience gives to his utterances peculiar value. Dr. Hardwicke recommends that ' the post-mortem room should be used only for the uncofined or unclaimed bodies awaiting identification, and ought to bo kept cool in summer by a supply of cold water; the corpse having sometimes to be preserved as long a time as possible from decomposition. This room should be furnished with special appliances necessary for post-mortem examinations; a marble or slate slab, with sides sloping towards the centre, converging into a drain below, so that fluids may not run over the edges; a sink with a plentiful supply of cold water ; an iron bowl; a coarse sponge ; a jack towel; a wooden yard measure; and, for the weighing of organs and structures, a set of weights and scales; a slated footboard around the slate table, on which medical men making post-mortem examinations may stand free from the damp or cold floor. Gas should be laid on, so as to procure warm water, or as it may be found necessary to make the examination at night, or when the darkness of winter days may obscure the view of the subject.'

A great deal of the success of a mortuary depends upon the efficiency of its keeper. The appointment of such an officer is absolutely necessary if scandal is to be avoided; but as to the amount of work to be required of him, everything must depend on the circumstances of the case. In mortuaries at cemeteries, the cemetery-keeper may properly supervise the mortuary; in mortuaries at hospitals, the porter or galdener: but as to mortuaries standing by themselves, no rule can be laid down. The duties, however, of the keeper have been thus defined by $\mathrm{Dr}$. Hardwicke in the paper already quoted :-

' His duties would be to receive under his charge not only bodies brought in by relatives and friends of the deceased, but those found dead by the police, or from accidents, or cases sent to the mortuary by the coroner's officer to await an inquest, or by the medical officer or sanitary inspector of the district, in order to relieve an overcrowded dwelling of a corpse dying from an infectious disease, or in a state of dangerous decomposition. He must act under fixed rules, and become responsible for the safe custody of these bodies and such articles of clothing as may accompany them. He must attend to the proper clennsing, disinfecting, and ventilation of the rooms generally, but especially of that used for post-mortem examinations and the room used for the reception of a corpso dead from an infectious disease. He must render some assistance to medical men who are called to make post-mortem examinations, in the placing of the corpse in and out of the shell; and his attendance is required upon persons visiting either for the purpose of identification or seeking information relative thereto. It is of the utmost importance that a mortuary lieeper should live very near the mortuary, so that he may always'be ready at all times to receive bodies. He should also keep a register of the mortuary, containing the date, name, sex, age, address, and other circumstances appertaining to the bodies to be removed; 
such as by whom, where to, or to what cemetery, or by what undertaker. ${ }^{1}$

The next point to consider is the regulation of mortuaries. As to this it seems to be generally agreed that the fewer regulations there are the better. Restrictions or forms of recommendation only tend to lessen the usefulness of mortuaries, and the best plan is to throw them open to every one who chooses to send a corpse thither. Dr. Letheby, in 1871, drew up an elaborate set of rules for the City Mortuary, but practically these have now fallen into complete desuetude. The subjoined rules, which are in force at the mortuary provided by the Islington Vestry in the Chapel of Ease grounds, Holloway Road, will be found to contain all that is essential in the matter :-

'The dead body shall be enclosed in a proper shell or coffin, such being the shell or coffin in which the body is to be buried, and shall be conveyed to the mortuary chamber, and also removed therefrom in a hearse, or other'wise in a decent and proper manner, and the undertaker or friend shall remove the dead body for interment within an ordinary specified time.

'In case the undertaker or friend fail to remove the dead body within the time specified, notice shall be given to the relieving officer of the parish to bury such body at the expense of the poor rate, such expense being subsequently recoverable from the parties legally responsible.

'A body having been brought or sent by any person whatsoever to the mortuary in a shell or coftin, such shell or coffin shall, under no circumstances, be removed other than for the burial of the body contained therein, unless such shell or coffin with the lid be properly lined with tinned copper.

'Should any shell or coffin sent with a body prove to be in a defective condition, a thoroughly sound and larger shell must upon notice be supplied, in which the defective shell can be enclosed, or in default the sanitary superintendent shall order a proper shell to be provided, and the expense will be recovered from the party sending such defective coffin.'

As to the reception of cases, there is a useful rule at the mortuary at Dean Street, Soho (which is under the control of the Burial Board of St. Anne, Westminster), empowering the attendant to receive a body without an order (other'wise necessary from a member of the Burial Board), if it be accompanied by a policeman or known inhabitant. At the mortuary in Drury Lane, which was established some years ago by Lady Burdett Coutts, Lord Vernon, and other benevolent persons; on the disused burial ground of the parish of St. Martin-inthe-Fields, there is a rule forbidding the admission of any public procession or large assemblage of persons into the grounds on the occasion of the admission or removal of the body. Only the immediate relatives, the undertakers, and bearers are allowed on the premises,-a commendable rule, which deserves imitation.

1 The scheme of duties for the keeper drawn up in 1871 by the late Dr. Letheby for the City Mortuary, or the Islingtou rules based upon it, may be recommended for general adoption. 
At this last mortuary bodies are received from 8 A.Mr. to 8 P.M from September 1 to April 30, and from 8 A.sr. to 10 P.M. from May 1 to August 31. Practically it would be found best to impose no limitation on the hours when bodies wre to be received, as it may often happen, especially during epidemic periods, that it is essential that the body of a person dead of infections disease shonld be removed instantly. It might be well, however, to have a general understanding on the subject, as at the City Mortuary, where all bodies are systematically removed by 11 P.M., though there are no specified hours named.

No charge should be levied on the relatives of the persons whose bodies are deposited in the mortuary, as it is rery important to encourage its use as much as possible. At none of the mortuaries of which I have information is such a charge made. The expenses of inquests held at the mortuary would of course be paid by the coroner.

The visits of friends and relatives need a word of mention. In most of the mortuaries that I am acquainted with there is no limitation to the unrestricted visits of friends within rensonable hours. At the Drury Lame mortuary the number of persons is restricted ta three, between the hours of nine in the morning and sunset; and at Hackney, where two mortuary chambers (one for acciclents and non-infectious diseases, and the other for infectious cases) have been provided, no one is allowed in the infectious disease chamber. At this mortuary infectious corpses are wrapped up in a sheet soaked with carbolic acid and water, and are placed in a shell when they arrive, if they are not brought in one. They are then transferred, as soon as possible, to a coffin in which sawdust and carbolic acid have been put, and the coftin is screwed down.

This leads me to the question whether or not it is necessary in providing mortuaries to have a separate chamber for infectious cases. I do not think that this separation will usually be found necessary, though, of course, there is an additional precaution when it is done. All infectious corpses ought certainly to be dealt with as at Hackney, and should be screwed down as soon as possible, a piece of glass being let. into the lid of the coffin in cases where it may be considered expedient or may be desired by the relatives. The question whether it should not be compulsory, without the necessity and uncertainty of applying to a justice, to send iufectious corpses to mortuaries from houses where proper isolation camnot be observed, is one upon which I can hardly express a decided opinion. It appears to me, however, to be eminently desirable from a sanitary point of view, and to offer hope of helping to diminish our yearly death-roll from preventable disease.

The public ought to have easy access to mortuaries, and every reasonable facility should be offered them for so doing. In those cases. in which the body of a person is found drowned, or is mknown or in other ways undistinguishable, provision should be made so that all the clothes of the deceased may be exposed to view. At present it is by no means easy for people who desire to view the bodies of unknown persons to accomplish their desire; and the natural consequence is that they come not to care to do so. The number of persons annually consigned to mother earth whose names and stations in life are utterly unknown is very large; and it cannot be doubted 
that if more easy means of ilentification were provicled, as by the exhibition of their clothes, we night reduce the number to an appreciable extent. Moreover, in this manner foul play might more readily be detected, and mysterious disappenunces clenred up. When it is borne in mind that of the three or four hundred persons annually exposed at the Morgue in Paris, half the identifications are due to chance; and that since greater facilities for the entry of the public to that institution have been made, the identifications have increased from barely three in every four bodies to nearly eight in nine, and that the police have been greatly assisted in the detection of crime, the importance of reasonably free access to a public mortuary will be recognised. I must guard myself against being supposed to advocrte the setting up in England of an institution like the Morgue, for the sensational sights exposed to public view in that building are clearly very undesirable. It is, nevertheless, of great importance to allow such free access as may help to assist in clearing up a mystery or may lead to the detection of a crime. Of course, the gratification of mere morbid curiosity must be strongly disencouraged, but it would not be at all difficult to do this with proper regulations. Many of the identifications at the Morgue, which is the most complete institution of its lind extant, are made through the clothes of the clecensed being conspicuously exposed; and the importance of preserving all articles of dress worn by an unrecognised corpse must therefore be strongly insisted on. At the Morgue a special room is provided for the retention of clothes of the unrecognised dead for from six to eight months after burial; but the number of deaths of persons unknown is likely to be so small at ordinary mortuaries that a box or press would be quite sufficient for the purpose.

I should wish, in conclusion, to say a fer words as to the burict. arrangements to be made by the managers of mortuaries. The length of time that should elapse between the reception of the body and the burial is of someimportance; and it will be observel that the justice's order referred to in section 142 of the Public Health Act may direct a body 'to be buried within a time to be limited in such order.' It becomes, therefore, of moment to know what should be the maximum time allowed. In England we have no power of requiring burial within a fixed period from death, though it is eminently desirable that we should have this power. It may not, perhaps, be generally known that in a Bill of 1842 there was a clause which proposed to provide that 'from and after the first day of October, one thousand eight hundred and forty _- , if any dead bocly shall continue unburied between the first day of May and the thirty-first day of October, both days inclusive, more than L hours, or between the first day of Nuvember and the thirtieth day of April, both days inclusive, more thim - hours, the executor's or administrators to the estate and effects of such deceased person, or the friends or relatives of the same, or any one of such friends or relatives present at the burial, or the occupier of the house from which such dend body shall be removed to be buried, shall forfeit the sum of twenty shillings for every twenty-four hours after the expiration of such respective periods.'

Nothing, however, came of this, and I do not think the question 
has again been raised. On the Continent, however, and in America, the state of affairs is different. Thus the New York Board of Health, whose sanitary regulations are extremely full and careful, have ordered that 'no person shall retain, or allow to be retained unburied, the dead body of any human being for a longer time than four days after the denth of such person, without a permit from the department, which permit shall specify the length of time during which such body may be retained unburied.' It would seem, therefore, wise to take this standard, and make regulations to the effect that a body must be removed from the mortuary within four days of the death. At Drury Lane every corpse must be remored for interment within six days from the date on which the death occurred. Corpses of persons dead of cholera must, however, be removed within two days, and those dead of other dangerous infectious diseases within three days, power being reserved to the Medical Ofticer of Health to order the interment of a rapidly decomposing corpse at any time.

As to the actual arrangements for interments, not much needs to be said. The portion of the Act clealing with this matter is not particularly clear, but Mr. Lumley, in his comments upon it, seems to think that the interment of bodies from a mortuary should, when necessary, be performed by the Sanitary Authority. In practice, however, burials from a mortuary that are not paid for by the relatives are performed by the Poor Law Authority, i.e. the Guardians. So far as I know, no legal question has jet arisen as to the interpretation of this clause; and probably it would be better not to distuxb the existing ariangements.

In thus endeavouring to give consideration to the subject of mortuaries in its various aspects, I fear I have been unduly prolix; but as no one else has yet grappled with the question in the fashion that I have attempted to clo, I have thought it desirable to place on record the facts that I have been able to gather together on this important subject, in the hope that they may be of assistauce to those who are striving to provide for the establishment of mortuaries in their midst. I am convinced that there is no subject more worthy of the attention of the clergyman, the philanthropist, and the sanitarian than that upon which your indulgence has permitted me thus to descant.

Henry C. Burdetr.

\section{APPENDIX.}

\section{LIST OF MORTUARIES.}

\section{A. Metropolis.}

In 1875 the British Medical Joumal tool measures for ascertaining the actual amount of mortuary accommodation existing in the Netropolis (see the No. for December 25, 1875, page 802). Since then certain other mortuaries have been constructed, but extensive districts in London are still without such a building. Of the following the author has particulars:-

Battersen.-A mortuary 'projected,' for six bodies, with post-mortem loom (A.D. 1875). 